\title{
PEMANFAATAN MEDIA BELAJAR POWERPOINT UNTUK MENINGKATKAN HASIL BELAJAR IPA SISWA KELAS VII B SEMESTER 2 TAHUN 2015 SMP NEGERI 3 BANYUBIRU
}

\author{
Purnomo, S,Pd \\ SMP N 3 Banyubiru \\ purkitri@gmail.com
}

\begin{abstract}
Media PowerPoint adalah merupakan media belajar yang dapat membantu guru dalam menyampaikan materi kepada siswa. Permasalahan yang muncul adalah apakah pemanfaatan media belajar PowerPoint dapat meningkatkan hasil belajar IPA pada konsep gerak. Penelitian dilakukan pada VIIB SMPN 3 Banyubiru Semester 2 Tahun Pelajaran 2014/2015 dengan dua siklus. Hasil penelitian menunjukkan bahwa ada peningkatan prestasi belajar IPA pada konsep gerak yaitu dari rata-rata nilai pada siklus I 70,33 menjadi 70,67 pada siklus II
\end{abstract}

Kata Kunci : Media belajar, Power Point dan Hasil Belajar IPA

\section{PENDAHULUAN}

Kondisi siswa-siswi SMP Negeri 3 Banyubiru dibandingkan dengan siswa siswi SMP se Kecamatan Banyubiru secara akademik termasuk rendah, hal ini dapat dilihat pada saat penerimaan siswa didik baru rata-rata nilai masuk di SMPN 3 Banyubiru tergolong rendah dibandingkan dengan sekolah lain. Maka setelah menjadi siswa di SMPN 3 Banyubiru, kendala yang dihadapi yaitu setiap proses pembelajaran setelah materi dijelaskan atau diakhir pelajaran setiap diberi pertanyaan lisan atau tertulis masih banyak siswa yang belum paham. Ini penulis alami ketika mengajar di kelas VII. Melihat keadaan seperti ini, tidak mengherankan jika guru belum dapat mengukur sebatas mana materi yang disampaiakan diserap oleh siswa. Dengan latar belakang masih banyaknya siswa yang belum paham akan berimbas pada nilai anak-anak baik nilai ulangan harian atau nilai ulangan semester. Masih banyaknya nilai ulangan harian IPA dibawah nilai KKM yang telah ditetapkan oleh sekolah untuk kelas VII semester 2 tahun 2014/2015 sebesar : 70,00 ( Tujuh puluh koma nol nol ). Akan berdampak pada nilai ulangan akhir semester yang akan digunakan untuk penilaian kenaikan kelas. Banyaknya anak-anak yang setelah ulangan harian mengikuti ulangan remedial menandakan anak-anak yang mengikuti tersebut mendapat nilai dibawah KKM. Pengalaman peneliti dari kebiasaan demikian adanya . Bukti dari diadakannya ulangan harian pada konsep Kinerja Ilmiah, dari sejumlah 30 siswa yang mendapat nilai diatas KKM ada :13 siswa, dan di bawah KKM ada : 17 siswa, nilai tertinggi 92,00 Dan terendah 51,00 Dengan nilai rata-rata : 69,07 . melihat nilai rata- 
rata kelas masih di bawah KKM 70,00, maka agar nanti pada saat diadakan Ulangan tengah semester 2 dan Ulangan Kenaikan Kelas tidak menjadi beban berat bagi siswa karena mata pelajaran IPA dianggap sulit, maka peneliti akan mengadakan penelitian di SMP N 3 Banyubiru, khususnya siswa kelas VII B, untuk tahun 2015.

Masih sedikitnya siswa yang mendapat nilai IPA di bawah KKM, dapat dimungkinkan karena cara peneliti menyampaikan materi kepada siswa kurang variatif, masih dengan metode ceramah walaupun sudah divariasi dengan diskusi kelompok atau tanya jawab. Peneliti belum memanfaatkan media belajar yang ada di sekolah seperti Power point.

Harapan akhir dari peneliti adalah sebelum dilakukan penelitian atau tindakan nilai rata-rata IPA 69, 07 setelah adanya tindakan nilai rata-rata IPA minimal bisa sama dengan KKM yaitu 70,00 atau bahkan lebih. Mengapa perlu ditingkatkan, karena agar anak-anak kelas VII B tidak banyak lagi yang mengikuti remedial, dengan tidak banyaknya siswa kelas VII B yang memperoleh nilai IPA di bawah KKM sudah meringankan beban anakanak, karena di semester 2 ( dua ) nanti akan ada Ulangan tengah semester 2 dan Ulangan Kenaikan Kelas.

Dengan sudah memanfaatkan media belajar power point harapan dari peneliti proses pembelajaran dapat: menyenangkan, memanfaatkan fasilitas yang ada, pembelajaran akan lebih terfokus pada materi, trampil menggunakan media belajar dan siswa lebih aktif.

Masih rendahnya Hasil belajar IPA siswa kelas VII B , harapannya hasil belajar IPA VII B meningkat. Kenyataan di kelas peneliti belum memanfaatkan media belajar power point, harapannya peneliti sudah memanfaatkan media belajar power point.

Dengan melihat kenyataan bahwa hasil belajar IPA siswa kelas VII B yang masih rendah, karena cara menyampaikan materi belajar yang masih menggunakan metode konvensiaonal yaitu dengan ceramah, diskusi yang sudah divariasi dengan tanya jawab, peneliti berusaha agar hasil belajar IPA kelas VII B meningkat, peneliti akan melakukan 2 (dua ) kali tindakan yaitu dalam menyampaiakan materi belajar akan menggunakan media belajar power point. Tindakan pertama menggunakan media belajar power point tanpa ada animasi baik tulisan, gambar dan suara. Tindakan kedua menggunakan media belajar power point yang menggunakan animasi baik tulisan gambar ataupun suara. Power point, selain tulisannya sangat jelas dibaca juga variasi tampilannya sangat menarik. Power point dapat dibuat tanpa animasi dan dapat dibuat dengan animasi berbagai variasi baik itu 
tampilan begrond, bentuk tulisan, jenis tulisan, tayangan atau slide show, efek suara dan lain sebagainya. Yang jelas dengan media power point harapan peneliti siswa akan jauh lebih tertarik sehingga materi yang disampaikan akan focus dan banyak dikuasai siswa sehingga, hasil belajar IPA terpadu juga meningkat.

Agar proses belajar mengajar tidak monoton, menjemukan, tidak menarik upaya yang dilakukan seorang guru berkaitan dengan proses belajar bermacam-macam cara . hal ini dilakukan agar setiap siswa memahami materi yang disampaikan oleh seorang guru. Tidak terkecuali menggunakan media yang ada disekolah atau tempat guru mengajar. Ada yang menggunakan media OHP, Charta, atau dengan media lainnya. Peneliti sudah menggunakan media OHP akan tetapi, dengan media OHP ternyata selaian cepat membosankan bagi siswa juga kurang menarik, karena hanya sebatas gambar mati. Selaian kurang menarik terhadapa siswa bagi peneliti sendiri menggunakan OHP juga termasuk boros karena plastic transparasi dan spidolnya juga mahal. Dan kalau dilihat hasil belajarnya juga kurang signifikan.

Oleh karena itu peneliti mencoba menggunakan media belajar yang berbeda yaitu dengan metode belajar power point menggunaka laptop dan ditayangkan menggunakan LCD Proyektor. Selain menarik juga sangat hemat dan efisien, hemat karena tidak selalu membuat efisien karena tinggal membuka di file yang telah disimpan di laptop. Siswa akan lebih konsentrasi karena media yang digunakan masih asing, disamping itu juga sangat menarik dari setiap materi yang disampaian karena adanya variasi tampilan, gerak dan suara. Maka agar kegiatan belajar mengajar berjalan tidak hanya satu arah, maka peneliti mencoba mengamati setiap kegiatan baik dari anak-anak yang berani menjawab pertanyaan serta hasil dari setiap pertemuan. Dan akhirnya harapan dari peneliti keberanian siswa menjawab pertanyaan dan hasil belajar jauh lebih baik dari media sebelumnya yaitu menggunakan OHP.

Power point suatu program computer yang biasanya digunakan untuk presentasi. Karena menggunakan power point dalam presentasi selaian hasilnya jelas juga sangat menarik bagi audiennya. Microsoft Office Power Point sebagai salah satu aplikasi diantara aplikasi-aplikasi office lainnya seperti Microsoft Word, Excel dan lain-lain, merupakan aplikasi yang digunakan untuk melakukan kegiatan presentasi, jadi anda dituntut untuk menguasai modul ini sampai anda dapat mempresentasikan dan bertugas sebagai presenter. Untuk penginstalan Microsoft Powerpoint biasanya proses penginstalannya bersamaan dengan aplikasi-aplikasi Microsoft Office lainnya seperti Microsoft Word, Microsoft 
Excel. Dan proses penginstalannya pada dasarnya semuanya sama. Yaitu dengan memasukkan CD drivernya ke dalam CD Room, ikuti instruksi yang diberikan masukkan serial numbernya ikuti instruksi berikutnya dan akhiri dengan finish. Kemudian kita telah dapat mengoperasikan microsoft office powerpoint yang telah terinstal tadi. Dengan demikian pembelajaran menjadi menarik sehingga hasil belajar siswa meningkat.

Menurut peneliti belajar adalah suatu proses yang secara berkesinambungan baik dari kegiatan formal atau non formal, yang dulunya tidak tahu sehingga menjadi tahu dan dapat merubah pengetahuan, perilaku, atau ketrampilan seseorang menjadi berbeda dari sebelum belajar. Menurut Gagne (1984) belajar didefinisikan sebagai suatu proses dimana suatu organisme berubah perilakunya akibat suatu pengalaman. Galloway dalam Toeti Soekamto (1992: 27) mengatakan belajar merupakan suatu proses internal yang mencakup ingatan, retensi, pengolahan informasi, emosi dan faktor-faktor lain berdasarkan pengalaman-pengalaman sebelumnya. Sedangkan Morgan menyebutkan bahwa suatu kegiatan dikatakan belajar apabila memiliki tiga ciri-ciri sebagai berikut. (1) belajar adalah perubahan tingkahlaku; (2) perubahan terjadi karena latihan dan pengalaman, bukan karena pertumbuhan; (3) perubahan tersebut harus bersifat permanen dan tetap ada untuk waktu yang cukup lama.

Berbicara tentang belajar pada dasarnya berbicara tentang bagaimana tingkahlaku seseorang berubah sebagai akibat pengalaman (Snelbeker 1974 dalam Toeti 1992:10) Dari pengertian di atas dapat dibuat kesimpulan bahwa agar terjadi proses belajar atau terjadinya perubahan tingkahlaku sebelum kegiatan belajar mengajar dikelas seorang guru perlu menyiapkan atau merencanakan berbagai pengalaman belajar yang akan diberikan pada siswa dan pengalaman belajar tersebut harus sesuai dengan tujuan yang ingin dicapai.

Dengan kata lain pembelajaran adalah proses membuat orang belajar. Guru bertugas membantu orang belajar dengan cara memanipulasi lingkungan sehingga siswa dapat belajar dengan mudah, artinya guru harus mengadakan pemilihan terhadap berbagai starategi pembelajaran yang ada, yang paling memungkinkan proses belajar siswa berlangsung optimal. Dalam pembelajaran proses belajar tersebut terjadi secara bertujuan dan terkontrol (Sukadi, 1984:8

Tujuan-tujuan pembelajaran telah dirumuskan dalam kurikulum yang berlaku. Peran guru disini adalah sebagai pengelola proses belajar mengajar tersebut. Dalam sistem pendidikan kita (UU. No. 2 Tahun 1989), seorang guru tidak saja dituntut sebagai pengajar yang bertugas menyampaikan materi pelajaran tertentu tetapi juga harus dapat berperan 
sebagai pendidik. Davies mengatakan untuk dapat melaksanakan tugasnya dengan baik seorang guru perlu memiliki pengetahuan dan pemahaman berbagai prinsip-prinsip belajar, khususnyai prinsip berikut (1) apapun yang dipelajari siswa, maka siswalah yang harus belajar, bukan orang lain. Untuk itu siswalah yang harus bertindak aktif; (2) setiap mahasiswa akan belajar sesuai dengan tingkat kemampuannya; (3) seorang siswa akan belajar lebih baik apabila mempengoreh penguatan langsung pada setiap langkah yang dilakukan selama proses belajarnya terjadi; (4) penguasaan yang sempurna dari setiap langkah yang dilakukan mahasiswa akan membuat proses belajar lebih berarti; dan (5) seorang siswa akan lebih meningkat lagi motivasinya untuk belajar apabula ia diberi tanggungjawab serta kepercayaan penuh atas belajarnya (Davies, 1971).

IPA di SMP/MTs, meliputi bidang kajian makhluk hidup dan proses kehidupan, energy dan perubahannya, materi dan sifatnya serta bumi dan alam semesta, dan yang sebenarnya sangat berperan dalam membantu peserta didik untuk memahami fenomena alam. Ilmu Pengetahuan Alam merupakan pengetahuan ilmiah, yaitu pengetahuan yang telah mengalami uji kebenaran melalui metode ilmiaha, dengan cirri : obyektif, metodik, sistematis, universal, dan tentatife. IPA merupakan ilmu yang pokok bahasannya adalah alam dan seisinya.

Carin dan Sund ( 1993) mendefinisikan IPA sebagai "pengetahuan yang sistematis dan tersusun secara teratur, berlaku umum ( universal ), dan berupa kumpulan data hasil observasi dan eksperimen.” Merujuk pada pengertian IPA itu, maka dapat disimpulkan bahwa hakekat IPA meliputi empat unsur utama yaitu: (1) sikap : rasa ingin tahu tentang benda, fenomena alam, makhluk hidup, serta hubungan sebab akibat yang menimbulkan masalah baru yang dapat dipecahkan melalui prosedur yang benar; IPA bersifat open ended; (2) proses: prosedur pemecahan masalah melalui metode ilmiah; metode ilmiah meliputi penyusunan hipotesis, perancangan eksperimen atau percobaan, evaluasi, pengukuran, dan penarikan kesimpulan; (3) produk: berupa fakta, prinsip, teori, dan hukum; (4) aplikasi : penerapan metode ilmiah dan konsep IPA dalam kehidupan sehari hari. Keempat unsur itu merupakan cirri IPA yang utuh yang sebenarnya tidak dapat dipisahkan satu sama lain. Dalam proses pembelajaran IPA kempat unsure itu diharapkan dapat muncul, sehingga peserta didik dapat mengalami proses pembelajaran secara utuh, memahami fenomena alam melalui kegiatan pemecahan masalah, metode ilmiah, dan meniru cara ilmuwan bekerja dalam menemukan fakta baru. Kecenderungan pembelajaran IPA pada masa kini adalah peserta didik hanya mempelajari IPA sebagai produk, 
menghafal konsep, teori dan hukum. Keadaan ini diperparah oleh pembelajaran yang beorientasi pada tes/ujian. Akibatnya IPA sebagai proses, sikap, dan aplikasi tidak tersentuh dalam pembelajaran.

Dalam arti luas IPA meliputi pembelajaran yang terpadu dalam satu disiplin ilmu, terpadu mata pelajaran, serta terpadu dalam dan lintas peserta didik (Fogarty, 1991 : Xiii). Pembelajara terpadu akan memberikan pengalaman yang bermakna bagi peserta didik, karena dalam pembelajaran terpadu peserta akan memahami konsep-konsep yang dipelajari melalui pengalaman langsung dan menghubungkannya dengan konsep-konsep lain yang sudah dipahami yang sesuai dengan kebutuhan peserta didik.

Untuk itu peneliti akan mengupayakan agar hasil belajar IPA kelas VII B pada Konsep gerak meningkat. Peneliti akan memanfaatkan media belajar dengan PowerPoint yang akan diproyeksikan dengan LCD proyektor.

Berdasarkan latar belakang, permasalahan yang muncul adalah apakah melalui pemanfaatan media belajar power point dapat meningkatkan hasil belajar IPA konsep pad siswa kelas VIIB semester 2 SMP Negeri 3 Banyubiru Tahun Pelajaran 2014/2015. Penelitian ini bertujuan untuk mengetahui peningkatan hasil belajar IPA konsep gerak melalui pemanfaatan media belajar power point pada siswa kelas VIIB semester 2 SMP Negeri 3 Banyubiru Tahun Pelajaran 2014/2015.

\section{METODE PENELITIAN}

Penelitian tindakan kelas ini dilaksanakan pada kelas VII B smester 2 SMP Negeri 3 Banyubiru tahun pelajaran 2013/2014. Penelitian akan dilaksanakan selama 5 (lima) bulan, mulai bulan Februari sampai dengan Juni 2014. Bulan Februari 2014 minggu ketiga dan keempat digunakan untuk : Menyusun proposal. Bulan Maret minggu pertama dan kedua digunakan untuk menyusun instrumen penelitian. Setelah menyusun proposal dan menyusun instrumen penelitian selesai dilanjutkan pengumpulan data pada siklus pertama pada minggu ketiga dan keempat bulan Maret Sedangkan siklus kedua dilaksanakan pada bulan April minggu pertama dan ke dua. Setelah selesai pelaksanaan siklus pertama dan kedua dilanjutkan dengan analisis data. Analisis data direncanakan selama 4 minggu yaitu minggu ketiga, empat dan lima bulan April dan minggu pertama bulan Mei. Kemudian dilanjutkan pembahasan atau diskusi memerlukan waktu selama 3 minggu yaitu minggu kedua, tiga dan empat bulan Mei. Begitu selasai pembahasan atau diskusi diteruskan pembuatan laporan memerlukan waktu lebih kurang 5 (lima) minggu, yaitu minggu kelima 
bulan Mei dan minggu pertama, kedua, ketiga dan keempat bulan Juni 2014. Subjek penelitian terdiri atas 30 siswa dengan jumlah laki-laki 16 orang dan 14 orang. Objek penelitian ini adalah Pemanfaatan media belajar power point yang diproyeksikan dengan LCD Proyektor untuk meningkatkan hasil belajar IPA bagi siswa kelas VII B pada konsep gerak. Data didapatkan dari hasil ulangan harian selama dua siklus. Dari data tersebut dianalisis secara kualitatif dan kuantitatif. Analisis kuantitatif menggunakan analisis diskriptif komparatif yaitu membandingkan hasil belajar kondisi awal, hasil belajar setelah siklus 1 dan hasil belajar setelah siklus 2. Kemudian dilanjutkan analisis kualitatif dengan membuat ulasan dari perencanaan, pelaksanaan, observasi dan refleksi.

\section{HASIL PENELITIAN DAN PEMBAHASAN}

Kondisi siswa-siswi SMP Negeri 3 Banyubiru dibandingkan dengan siswa siswi SMP se Kabupaten Semarang secara akademik termasuk rendah, hal ini dapat dilihat pada saat hasil ujian nasional diberikan, peringkat nilaia UN masih kisaran 50 an, dimungkinkan saat kendala yang dihadapi yaitu setiap proses pembelajaran setelah materi dijelaskan atau diakhir pelajaran setiap diberi pertanyaan masih banyak siswa yang belum berani menjawab pertanyaan baik itu pertanyaan lisan atau tertulis. Ini penulis alami ketika mengajar baik di kelas VII dan VIII . Melihat keadaan seperti ini, tidak mengherankan jika guru belum dapat mengukur sebatas mana materi yang disampaikan diserap oleh siswa. Dengan latar belakang masih banyaknya siswa yang belum berani mengemukakan jawaban setiap kali diberi pertanyaan oleh guru akan berimbas pada nilai anak-anak baik nilai ulangan harian atau nilai ulangan semester. Masih banyaknya nilai ulangan harian IPA dibawah nilai KKM yang telah ditetapkan oleh sekolah untuk kelas VII semester 2 tahun 2013/2015 sebesar: 70,00 ( tujuh puluh koma nol nol ). Akan berdampak pada nilai ulangan akhir semester yang akan digunakan untuk penilaian kenaikan kelas. Banyaknya anak-anak yang setelah ulangan harian mengikuti ulangan remedial menandakan anakanak yang mengikuti tersebut mendapat nilai dibawah KKM. Pengalaman peneliti dari tahun ke tahun juga demikian adanya . Bukti dari diadakannya ulangan harian BAB I dengan Konsep Pengamatan Gejala Alam, dari sejumlah 30 siswa yang mendapat nilai diatas KKM ada :13 siswa, dan di bawah KKM ada : 17 siswa, nilai tertinggi 92,00 Dan terendah 51,00 Dengan nilai rata-rata: 69,07. Melihat nilai rata-rata kelas masih di bawah KKM 70,00, maka agar nanti pada saat diadakan Ulangan tengah semester 2 dan Ulangan Kenaikan Kelas, tidak menjadi beban berat bagi siswa karena mata pelajaran IPA 
dianggap sulit, maka peneliti akan mengadakan penelitian di SMP N 3 Banyubiru, khususnya siswa kelas VII B, untuk tahun 2015. Hasil Ulangan BAB 1 dapat dilihat pada Tabel 1.

Tabel 1. Nilai Ulangan Konsep Pengamatan Gejala Alam

\begin{tabular}{clc}
\hline No. & \multicolumn{1}{c}{ Uraian } & Ulangan Harian \\
\hline 1. & Nilai Terendah & 51,00 \\
2. & Nilai Tertinggi & 92,00 \\
3. & Nilai Rerata & 69,07 \\
4. & Rentang Nilai & 41,00 \\
\hline
\end{tabular}

Masih sedikitnya siswa yang berani menjawab pertanyaan baik lisan dan tertulis dan banyaknya siswa yang mendapat nilai IPA di bawah KKM, dapat dimungkinkan karena cara peneliti menyampaikan materi kepada siswa kurang variatif, masih dengan metode ceramah walaupun sudah divariasi dengan diskusi kelompok atau tanya jawab. Peneliti belum memanfaatkan media belajar yang ada di sekolah seperti LCD proyektor dan Power point.

\section{Hasil Siklus I}

Pada tahap perencanaan, peneliti membuat RPP konsep: (1) Kedudukan dan Perpindahan, (2) Kelajuan dan Kecepatan untuk 3 x pertemuan, Tahap perencanaan peneliti menyampaikan apersepsi yang berkaitan dengan materi gerak, misalnya apakah mobil yang berjalan di jalan raya melakukan gerak mempunyai kecepatan?, apakah tumbuhan dipinggir jalan juga ikut bergerak jika pengamat didalam mobil mempunyai kelajuan? Siswa diberi kesempatan menjawab pertanyaan itu.

Pada tahap pelaksanaan peneliti mulai menyampaikan materi gerak selama 2 kali pertemuan dengan power point yang diproyeksikan dengan LCD proyektor. Peneliti tidak menggunakan animasi baik tulisan, warna, gambar, suara atau istilahnya biasa saja. Materi yang peneliti sampaikan yaitu pada pertemuan 1, Kedudukan dan Perpindahan, dan pertemuan ke 2 , Kelajuan dan Kecepatan.

Tahap pengamatan mula-mula peneliti membentuk kelompok kecil setiap kelompok terdiri dari 4 -5 orang, pada siklus1 pertemuan pertama penelitia menyampaikan materi Kedudukan dan Perpindahan. Selama proses pembelajaran anak - anak sudah mulai mengenal LCD, power point, banyak anak - anak yang rasa ingin taunya tinggi, banyak 
pertanyaan yang diajukan siswa walaupun tidak semuanya sesuai materi yang diajarkan, paling tidak pembelajaran sudah hidup. Ada anak yang menanyakan kok tulisannya biasa saja pak tidak ada bunyinya. Peneliti jawab nanti pertemuan ke tiga setelah ulangan, akan kami tampilkan. Kegiatan pembelajaran pada siklus 1 pertemuan ke 2 peneliti membentuk kelompok kecil antara 4-5 orang menyampaikan materi Kelajuan dan Kecepatan. Peneliti menyampaiakan materi dengan gambar - gambar anak - anak sangat antusias mengikut pelajaran sudah banyak anak yang bertanya walaupun kelas terdengar rame tetapi pembelajaran sangat menyenangkan, sebelum mengakiri pertemuan peneliti menyampaikan pengumuman bahwa pertemuan yang akan datang ulangan konsep Kedudukan dan perpindahan serta Kelajuan dan Kecepatan. Pertemuan ketiga Peneliti melaksanakan test untuk mengambil nilai anak - anak. Bentuk tes tertulis pilihan ganda dengan jumlah 15 soal. Hasil tes dapat dilihat pada Tabel 2.

Tabel 2. Nilai Hasil Belajar Pada Siklus 1

\begin{tabular}{clc}
\hline No. & \multicolumn{1}{c}{ Uraian } & Ulangan Harian \\
\hline 1. & Nilai Terendah & 53,00 \\
2. & Nilai Tertinggi & 93,00 \\
3. & Nilai Rerata & 70,33 \\
4. & Rentang Nilai & 40,00 \\
\hline
\end{tabular}

Pada tahap refleksi muncul pertanyaan mengapa nilai ulangan hariannya masih kurang memuaskan?, mengapa yang bertanya masih orang itu itu saja walaupun sudah mulai banyak yang bertanya? Pertemuan berikut akan menggunakan power point dengan animasinya anak - anak untuk belajar dulu dirumah.

\section{Hasil Siklus II}

Pada tahap perencanaan, peneliti membuat RPP untuk 3 x pertemuan, pertemuan 1 Konsep Gerak Lurus Beraturan dan Pertemuan Ke 2 Konsep gerak Lurus Berubah Beraturan. Tahap perencanaan peneliti menyampaikan apersepsi yang berkaitan dengan materi gerak, misalnya apakah mobil yang berjalan di jalan raya mempunyai gerak lurus ? apakah jarum Arloji Bergerak Lurus? Gerak apa mangga yang jatuh ke tanah ? Siswa diberi kesempatan menjawab pertanyaan itu. 
Tahap pelaksanaan peneliti mulai menyampaikan materi Gerak Lurus Beraturan selama 3 kali pertemuan dengan power point yang diproyeksikan dengan LCD proyektor. Peneliti sudah menggunakan animasi baik tulisan, warna, gambar, suara atau gerak . Materi yang peneliti sampaikan yaitu pada pertemuan 1, konsep Gerak Lurus Beraturan dan pertemuan ke 2 , Gerak Lurus Berubah Beraturan, dan Pertemuan Ke 3 ulangan harian dengan test tertulis sejumlah 10 soal .

Tahap pengamatan, mula - mula peneliti membentuk kelompok kecil setiap kelompok terdiri dari 4 -5 orang, pada siklus 2 pertemuan pertama penelitia menyampaikan materi Gerak Lurus Beraturan. Selama proses pembelajaran anak-anak sudah mulai paham bahkan membantu memasang konektivitas Laptop ke LCD. Penelitia menyampaikan materi dengan power point, yang sudah dianimasikan baik tulisan, warna, gambar, suara . gerak . Anak - anak sangat senang sekali. Banyak pertanyaan dari siswa, bahkan ada siswa yang juga bisa menjawab pertanyaan dari temannya. Pada siklus kedua untuk pertemuan ke 2 peneliti meyampaikan materi Gerak Lurus Berubah Beraturan. Peneliti menyampaiakn dengan banyak contoh gambar dan animasi, anak - anak sangat senang dan termotivasi, sebelum mengakiri peneliti meyampaikan informasi bahwa minggu depan ulangan konsep Gerak Lurus Beraturan serta Gerak Lurus Berubah Beraturan. Ulangan harian tertulis dengan 10 soal pilihan ganda. Hasil ulangan siklus 2 dapat dilihat pada Tabel 3.

Tabel 3. Nilai Ulangan Harian Suklus 2

\begin{tabular}{clc}
\hline No. & \multicolumn{1}{c}{ Uraian } & Ulangan Harian \\
\hline 1. & Nilai Terendah & 50,00 \\
2. & Nilai Tertinggi & 90,00 \\
3. & Nilai Rerata & 70,66 \\
4. & Rentang Nilai & 40,00 \\
\hline
\end{tabular}

Tahap refleksi melihat nilai ulangan harian ke 2 sudah menunjukkan kemajuan terbukti nilai rata-ratanya meningkat. Sudah banyak siswa yang bertanya baik materi pelajaran atau bagaimana cara membuat power point. Metode ini bisa dipakai materi berikutnya agar nilainya semakin baik.

Microsoft PowerPoint adalah salah satu media pembelajaran dengan menggunakan animasi tulisan, suara, gambar. Dengan media ini telah memberi optimalisasi dalam proses pembelajaran khususnya mata pelajaran IPA. Dengan 
menggunakan media power point dapat mengaktifkan, mengkreatifkan dan menciptakan pembelajaran yang menyenangkan. Media belajar dengan power point tanpa animasi memberikan hasil yang kurang maksimal jika dibandingkan dengan Powerpoint yang menggunakan animasi, dengan demikian metode ini bisa digunakan untuk materi yang lain atau mata pelajaran yang lain. Melalui PowertPoint tersebut pembelajaran IPA konsep gerak dapat ditingkatkan hasil belajarnya.

\section{KESIMPULAN}

Media pembelajaran PowerPoint dapat meningkatkan hasil belajar IPA konsep gerak sebesar 0,30. Selain itu siswa juga muncul kreativitas, rasa berani, dan pembelajaran menjadi menyenankan. Berdasarkan penelitian ini disarankan untuk menggunakan media PowerPoint untuk membelajarkan materi yang lain di semua mata pelajaran. 


\section{DAFTAR PUSTAKA}

Arikunto, S., dkk. 2006. Penelitian Tindakan Kelas. Jakarta: PT Bumi Aksara.

Purnomo, B. Kumpulan Karya Tulis Ilmiah Strategi Naik Pangkat dari IV a ke IV b. Yogjakarta: Penerbit Dafa Bintang Reksa.

Depdikbud, 2003. Undang-Undang republik Indonesia Nomor 20 tahun 2003 tentang sistem Pendidikan Nasional Dikmenum, Jakarta: Depdikbud.

Departemen Pendidikan Nasional, 2007. Manajemen Sekolah. Materi Pelatihan Kepala Sekolah tingkat Nasional.

Mulyadi, HP. 2007. Materi: Pengantar Pengembangan Profesi. Materi Pelatihan Karya Tulis Ilmiah dan manajemen Sekolah. Salatiga

Kemendikbud 025/O/1995: Petunjuk Teknis Ketentuan Pelaksanaan Jabatan fungsional Guru dan angka kreditnya. Jakarta: Depdikbud

Kemenpannomor 84 /1993: Jabatan fungsional Guru dan angka kreditnya. Jakarta: Depdikbud

Keputusan Bersama Menteri Pendidikan dan kebudayaan dan Kepala Badan Administrasi Kepegawaian Negara Nomor ; 0443/P/1993 , nomor ; 25 Tahun 1993 tentang Petunjuk Pelaksanaan Jabatan Fungsional Guru dan Angka Kreditnya.

PS, Djawanto,PS. 2000. Pokok-pokok Metode Riset dan Bimbingan Teknis Penulisan Skripsi. Yogjakarta, Yogjakarta: Liberty 